\title{
Challenging the Whiteness of Britishness: Co-Creating British Social History in the Blogosphere
}

\section{Deborah Gabriel, Bournemouth University, UK}

\begin{abstract}
Blogs are a valuable medium for preserving cultural memory, reflecting the various dimensions of human life (O'Sullivan, 2005) and allowing ordinary individuals and marginalised groups the opportunity to contribute to the 'dialogue of history' (Cohen, 2005:10). The diverse perspectives to be found in the blogosphere can help deepen understanding of historical moments. Such examples include 9/11 (Cohen, 2005), the London bombings in 2005 (Allan, 2006) and Hurricane Katrina (Brock, 2009). Using critical race theory (CRT) as a theoretical framework and cultural democracy as the conceptual framework, this study examines the symbolic power of counter-storytelling through the blogosphere. The findings reveal that in relation to coverage of the UK 'riots' in 2011 and the Stephen Lawrence verdict in 2012, African Caribbean bloggers advanced alternative perspectives of the events and appropriated blogs as a medium for self-representation through their own constructions of Black identity. In so doing they performed a vital role as cocreators of British social history.
\end{abstract}




\section{Introduction}

Historical archives in Britain often exclude or fail to capture the presence and experiences of people of colour (which dates back to the $17^{\text {th }}$ century with the first arrival of slaves from the west coast of Africa), resulting in a 'whitenening of Britishness' Bressey (2006:51). The term is defined as a process through which the exclusion of a person's skin colour in historical records results in the assumption of a white identity (Bressey, 2006). In the $21^{\text {st }}$ century, while the Census captures the ethnic and cultural diversity of the British population, the mainstream media remains a key terrain for on-going struggles against hegemony (Bailey et al, 2008; Downing, 2001; Cammaerts, 2008). How African Caribbean people are represented within the mainstream media through dominant discourses is a key concern. Research suggests that they are frequently framed as social problems (Law, 2002) through racist discourse (Van Dijk, 2006). Therefore it can be argued that 100 years from now, historians analysing news archives will be confronted with a version of history that is equally borne of the white imagination, told from the perspectives of the white middle classes who make up 96 per cent of journalists working in the UK (Journalism Training Forum, 2002). Under such circumstances, the role that bloggers play in providing broader socio-cultural perspectives of historical moments is of major significance. Who better can critique mainstream representation that continues to perpetuate problematic stereotypes than the communities on the receiving end of such racial oppression?

This study therefore examines blogs as a medium for reflecting the varied dimensions of human experience (O'Sullivan, 2005). It explores the role that African Caribbean bloggers played in contributing to the dialogue of British social history in coverage of the UK 'riots' in 2011 and the Stephen Lawrence verdict in 2012. Throughout this paper, the term 'racialised minority' is used in preference to the term 'ethnic minority', since the latter does not reflect the cultural reality of the world we live in (where people of white, European descent represent the minority ethnic group); serving only to reinforce notions of inferiority and superiority (Aldridge, 2000). The term 'racialised minority' exposes the hidden presence of whiteness by emphasizing that people of colour are located outside the realm of Britishness and positioned at the bottom a social hierarchy in relation to white identity, creating boundaries of inclusion and exclusion (Campbell, 2008).

\section{Literature Review}

\section{Whiteness In The Mainstream Media}

A lack of newsroom diversity has often been cited as a contributory factor to the marginalisation and misrepresentation of racialised minority groups across the mainstream media (Ainley, 1998; Cottle, 2000; Kretzschamar, 2007; Van Dijk, 2006). A large scale survey of the industry revealed that just $4 \%$ of UK journalists are from a racialised minority background (Journalism Training Forum, 2002). Several scholars have examined how media discourse reproduces racism including Law (2002) and Van Dijk (2006), among others. Racist discourse is defined as a form of social practice linked to personal beliefs and attitudes about people from racialised minority backgrounds that can lead to racist behaviour or discriminatory practices (Van Dijk, 2006). The role of the media is of major significance since it reproduces negative stereotypes of racialised minorities which can influence perceptions about these groups. This frequently involves focusing on social differences where racialised minorities are presented as social problems (Parekh Report, 2000; Van Dijk, 2006).

CRT with its focus on the collective and cumulative effects of racism as it operates on structural levels has been used to explain through the concept of whiteness, how the media reproduces racism. Whiteness has been conceptualised as a multi-faceted social construct that 
functions to maintain white supremacy; (Owen, 2007) a system of unearned privileges (Kendal, 2006; Mc Intosh, 1988) and by the exclusion of others racialised as non-white (Gillborn, 2008). White supremacy has been defined as:

A political, economic and cultural system in which whites overwhelmingly control power and material resources, conscious and unconscious ideas of white superiority are widespread, and relations of white dominance and non-white subordination are daily re-enacted across a broad array of institutions and social settings. (Frances Lee Ansley cited in Gillborn, 2008:36)

The power of whiteness as it functions through the media is its invisibility (Gabriel, 1998), whereby what are essentially European values, beliefs, practices and traditions are universalised and presented as the defining principles that apply to all cultures (Fiske, 2000). Racist discourse is often framed in the media through news stories where racialised minorities are deemed as social problems to society and occupy the realm of the racialised other (Van Dijk, 2000). Despite this, racist discourse is often obscured as negative stories about racialised minorities which follow common themes such as immigration and racialised crime such as mugging, often appear at the same time that messages of social inclusion and anti-racism are disseminated in the news. Contextual analysis by Ian Law (2002) of news content in the British media between November 1996 and May 1997 revealed that racialised minorities were constructed as social problems in $11 \%$ of items, compared with coverage of their contribution to society, which occurred in just $4.5 \%$ of items. Much wider coverage was given to individual contributions of racialised minorities than the contributions of minorities as a group. The emphasis on individual achievement promotes the view that racism does not exist, since individuals are held up as examples of success; while collective experiences of educational underachievement and unemployment are deemed to be self-induced and caused by a lack of ambition, lack of motivation and laziness. The same study found that a third of tabloid newspapers and a quarter of broadsheets carried negative stories about racialised minorities. While some newspapers appeared to carry anti-racist messages, this was deemed to be a strategy for:

Masking continuing normative and progressive whiteness in news organisations, racial and ethnic inequalities of power and employment and a collective failure to provide appropriate quality news services for Black and minority ethnic communities and consumers (Van Dijk, 2000:159).

Highlighting how African Caribbean communities are frequently framed as social problems through dominant discourses in the mainstream media provides an important socio-political context for this study by emphasising the need to provide alternative perspectives.

\section{Blogs as Historical Archives}

Blogs function as a valuable medium for preserving cultural memory alongside traditional archives. As online diaries, they serve the same purpose as traditional diaries as a 'window onto the past'. They reflect the varied dimensions of human life 'in a particular time and place' and 'often provide interesting, insightful or humorous perspectives on contemporary events' (O'Sullivan, 2005:54). Along with other forms of electronic communication, blogs helped to provide an expansive record of the events of September 11 2001, reflecting the growing significance of ICTs as part of America's cultural output. Led by the Pew Internet and American Life Project, the Library of Congress archived 30,000 websites between September 11 and December 1 2001. A significant benefit of blogs which is of particular relevance to this study is that 'they allow ordinary people and marginalised constituencies... a 
more important role in the dialogue of history' (Cohen, 2005:10). The diverse perspectives to be found in the blogosphere can lead to new interpretations or help deepen understanding of a historical moment. For example, digital archives created after September 11, reveal that ordinary Americans viewed the terrorist attacks in personal terms through the loss of loved ones or devastation to their communities and not in nationalistic terms, as might have been expected (Cohen, 2005). During the London bombings in 2005, ordinary citizens caught up in the chaos became accidental journalists, relaying what they witnessed and offering personalised accounts of traumatic events. London's blogging community in particular, mobilised to provide news and information including photographs, video clips, survivor's diaries and names of victims, helping to piece events together. Numerous blog posts were used by mainstream news organisations such as the $B B C$ and Guardian, helping to enrich and further contextualise mainstream reporting on the bombings (Allan, 2006).

Previous research provides useful examples of how blogs have captured pivotal moments in Black History. Moyo's (2011) study on bloggers' reporting of the Zimbabwean elections in 2008 demonstrates the important role that they played in documenting the country's political history in the absence of mainstream journalists. During the elections, press restrictions resulted in the alleged arrest, torture and murder of professional journalists for criticising the government. Facilitated by Kubatana, a civic organisation focused on democracy and human rights; ordinary citizens used blogs as a platform to produce and disseminate news stories documenting human rights abuses and violence during the elections. Stories reported vote rigging, violence, rape, abductions, torture, hunger and starvation. They captured an important moment in Zimbabwe's political and social history in the wake of censorship and functioned as an alternative public sphere through which opinions were formulated, nurtured and sustained during the elections.

Another study by Brock (2009) examines websites maintained by African Americans (mostly blogs) in the aftermath of Hurricane Katrina. Analysis of the content reveals their observations and experiences of racism. For example, African Americans were referred to as refugees, while whites were automatically assumed to be American citizens. This culminated in American-born Blacks being refused aid that was provided to foreign-born white Americans. As Brock (2009:103) argues, African Americans used blogs 'to express their entitlement to citizenship in a country they were born in, worked in and died for'. Racist representations of African Americans during Hurricane Katrina have been well documented by academics and intellectuals. This includes analysis of the mainstream media's tendency to associate African Americans with crime and violence and inaccurate reporting of criminality where whites were depicted as survivors and Blacks as looters (Sommers et al, 2006; Troutt, 2006). However, blogs captured the unique and personalised perspectives of ordinary African Americans on a major national disaster that occurred in the largely Black population of New Orleans. Their blogs represent 'a coherent presentation of African American identity' while further demonstrating how blogs were appropriated 'to reify their right to citizenship and humanity' (Brock, 2009:104).

According to historian Mary Friedman, blogs can serve an important function in documenting social history. Mommy bloggers (mothers who blog about their family and life experiences) are co-creators 'of maternal history...the history of mothers at this moment in time' (Friedman, cited in Leow, 2010:238). It is further argued that topic-based blogs can be regarded as 'archives in the making' and therefore every blog 'is a potential historical source' (Leow, 2010:239). Using the same logic as Friedman and Leow, it is argued here that African Caribbean bloggers in the UK can be conceptualised as co-creators of British social history. 


\section{Methodology \& Research Methods}

This study is approached through the theoretical framework of CRT and the conceptual framework of cultural democracy. CRT is an interdisciplinary movement of scholars and activists seeking to study and transform the relationship between race, racism and power in the privileging of white social, economic and political interests developed in the US in the 1970s. Its defining principle is the acknowledgement that racism is deeply ingrained within the fabric of American society to the extent that it has become normalised and taken-forgranted and appears natural (Delgado and Stefancic, 2001). Despite its American origins, CRT is used by scholars worldwide to examine the experiences of people of colour across a range of academic disciplines. Adopting CRT as a methodological approach for this study helps to contextualise the historical experience of African Caribbean people by highlighting how dominant discourses in the British mainstream media can perpetuate stereotypical and negative representations of racialised minorities. CR is used also as praxis to capture the unique perspectives of African Caribbean bloggers in Britain through in-depth interviews. One of the principle tenets of CRT is that it is grounded in the experiences of people of colour. As Milner (2007:391) argues: 'From critical race theory perspectives, knowledge can and should be generated through the narratives and counter-narratives that emerge from and with people of colour'.

Cultural democracy advances the view that within a diverse society, all ethnic and cultural groups have a human right to equality of opportunity and equal access to power. Within this framework, power is defined as the capacity to have an effective voice to advance one's view of the world and one's place within it as an active participant (Aldridge, 2000). It recognises the intersections between knowledge, culture and power and offers an effective approach through which to scrutinise and deconstruct unequal power relations in and through the mainstream media.

This study is based on in-depth interviews in 2012 with two male and two female African Caribbean bloggers based in the UK extracted from a larger sample of 30 participants sourced through accidental and random sampling. This study emerged from a larger inquiry into the use of blogs among African Caribbean people in the UK and relates to the research question: how do African Caribbean people in the UK use bogs to address issues of representation in the mainstream media? Two of the interviews were conducted face-to-face at the British Library and two were via telephone. Thematic data analysis has been used as an inductive approach to identify key themes emerging from the data as outlined by Harding (2013), Le Compte (2000) and Thomas (2006). The findings are presented as a combination of narratives from the interviews and extracts of the blog post referred to during interview. The languagein-use method of discourse analysis developed by Gee (2005) has been employed as an analytical approach to capture the social, cultural and political meanings of their narratives.

\section{Analysis \& Discussion \\ Uk 'Riots' Blamed On 'Black Culture'}

In August 2011 Mark Duggan, a 29 year-old father of four of mixed heritage was shot dead by a Metropolitan police officer in Tottenham, north London, sparking a wave of national protests. What started as a peaceful demonstration outside Tottenham Police Station on 6 August descended into violence as petrol bombs were thrown at police and buildings and shops were set alight. By 8 August protests flared up in several other British cities including Birmingham, Liverpool, Nottingham, Bristol and Manchester. It emerged later that Duggan was not in possession of a firearm at the time of his attempted arrest but an inquest ruled his death lawful (BBC News, 2014). The public discourse after August 2011 delegitimised the 
idea that events represented protests against injustice and instead were used to mount attacks against multiculturalism. Speaking on BBC Question Time, historian David Starkey used the events to demonise Black communities and the white working class. He suggested that they constitute a criminal underclass motivated purely by a desire to acquire consumer goods through illegal means: 'these weren't protests, these were shopping with violence' (cited in Jensen, 2013:1:3). Through this discourse, the concerns and frustrations of those who participated in the unrest were swept aside, and served the purpose of 'personalising and individualising property and disadvantage' (Jensen, 2013:5:4). Since Starkey's professional interests lie with the upper classes, his racialisation of the riots also reflect a distaste of the working classes, who he claims have adopted a 'Black' identity. In blaming Black culture for widespread public disorder he 'essentialises whiteness as good (and English) and Blackness as its antithesis' (Phoenix \& Phoenix, 2012:62). Much of the negative media coverage that racialised the riots focused on young Black males and the working class, demonstrating that contemporary racism is intersectional in nature with its emphasis on race, class and gender. Gaudio \& Bialostok (2005) argue that there is a tendency among white middle class social actors to attribute social and economic inequalities among racialised minorities to cultural differences, which are often perceived as deficiencies. In doing so they fail to acknowledge white privilege or barriers based on race and class, and take no responsibility for addressing racial inequality, since they perceive that assimilating into 'white' culture will lead to social and economic advancement. Culture is therefore perceived as a hierarchical system of values in which white, middle class cultural values are routinely accepted as superior to those of racialised minorities. Culture has therefore become a mask that hides racist ideology since there is rarely any historical reference to the fact that the political and economic systems in the US and elsewhere are racially stratified and promote white racial power and privilege. Although racism was once premised on presumed biological differences, culture is now invoked as a justification for racial inequalities and 'effectively serves as a euphemism for race' (Gaudio \& Bialostok, 2005:54).

During an interview in 2012, Adrian, one of the participants, aged 30 who describes himself as a social commentator stated that misrepresentation of Black communities was amplified in media coverage of the UK riots in 2011:

I personally don't think the riots were a race issue. I think the problem was a class issue...A lot of the mainstream media was like let's look at Black leaders and okay that's fine because Tottenham is a predominantly Black area. But it's also a Turkish area, a Kurdish area and all the kids that were rioting were not all Black. It really annoyed me that you were seeing all this stuff in the media and it's like they've clearly not done their research about what happened. The mainstream media is often quite lazy when it comes to these issues. It's like, let's just go for the easy target.

Extracts of his blog post below reveal his own analysis of how the riots were racialised by the mainstream media, misrepresenting Black communities, who bore most of the blame for the widespread social unrest:

The events that preceded the initial riots in Tottenham were the death of Mark Duggan and a subsequent peaceful protest on the Saturday afternoon before the rioting commenced. Several commentators attempted to make hurried and tenuous links between the peaceful protest and the rioting. However, there was no correlation between the aims of the initial protesters who 
sought answers over the death of Mark Duggan and the rioters who sought opportunistic destruction.

... any indignation of the rioters in Tottenham, and the locations of subsequent rioting, was not apparent. Nonetheless, a number of rioters and commentators claimed the death of Mark Duggan served as a tipping point for frustrations of disaffected youth, particularly within the Black community and anger over racial profiling.

In the aftermath of the unrest, socio-economic, racial and generational tensions have all been opined as the cause of the riots along with wider community tensions with the police. Finding a neat social group by which the rioters can be identified appears to be much desired.

The extent of British multiculturalism has been apparent in the varied ethnic groups of the rioters. To suggest a link between race relations and the unrest is therefore a flawed assumption. Nonetheless, some commentators, both within and outside of the Black community, have attempted to argue this case. However, historian David Starkey, in what were career-ending utterances on the BBC's Newsnight, went one step further.

Referencing Enoch Powell's 'Rivers of Blood' speech that criticised commonwealth immigration to Britain, David Starkey asserted "Black culture" had been assumed by nonBlack rioters, effectively equating Black culture with the nihilistic behaviour that was witnessed in several English cities. Conversely, claiming Black Labour MP David Lammy's well-educated diction as that of a white person, he intimated white culture was the antithesis of all that had occurred with the unrest.

Needless to say, David Starkey's comments were unfounded and utterly racist, totally rejecting the many positive contributions the Black Diaspora, and those of other ethnic minority communities, has made to British society.

There was not a 'Black' issue behind the riots. The issue of race relations, let alone one exclusive to the Black community, was very much secondary, if at all applicable, to the cause of the riots.

Adrian's post revels his perception that through the dominant discourses in the mainstream media following the 'riots', Black cultural identity was problematized, demonized, criminalized and devalued as Black communities were used as a scapegoat by some journalists and commentators seeking a facile explanation of the events to present to the British public. In particular, Adrian sees the use of language as a mechanism to construct the Black population as the 'other' as polluters of legitimate Britishness restricted to white Europeans. This is evidenced through Adrian's reference to historian David Starkey attributing the social disorder to Black culture and by default Black communities through reference to wider problems around mass immigration. Starkey's essentialist conceptualisation of Black identity viewed from a white imperialist perspective equates formal English language with whiteness. This is exemplified by his appropriation of MP David Lammy as an example of a Black male that embodies whiteness. By contrast, the informal language sometimes referred to as urban slang, is equated with Black culture and viewed as illegitimate and inferior.

Adrian's observations and analysis are not dissimilar to theoretical interpretations on racist discourse found in the literature. For example, in his examination of the relationship between racism, discourse and ideology, Van Dijk (2000) argues that racist ideologies are reproduced through talk and text (as exemplified by Starkey's comments on prime time television). They 
are characterised by a strategy that seeks to ascribe negative attributes to racialised others, whilst presenting whites as victims. In the example above, white British society is presented as a victim of Black culture that is linked with illiteracy, violence and social disorder. Racist ideologies often frame Black communities as social problems, focusing on social differences which are presented as negative traits that threaten the stability of white British society. Carter et al (1996) argue that the British state has played a key role in the racialization of migration and in the construction of national identities, through which race is signified as a location of difference. Studies have shown that the mainstream media consistently produces negative and alarmist coverage of immigration issues that uncritically repeats and therefore perpetuates racist discourse by government ministers who use metaphorical terms like 'tides', 'floods' and 'swamping' (Law, 2002: 91).

By contrast, Mitchell, a 44 year old blogger who writes about current affairs, focuses less on critiquing white, middle class commentators and instead draws attention to the absence of the perspectives of those who participated in the protests. He attaches significance to his own voice being heard and contributing to the national debate: 'One of the deepest posts I've written is about the riots', which suggests that his post was crafted after considerable reflection on the events. In the aforementioned blog post which centred on the causal factors that initiated the disturbances, he opined:

The true answers lie with the rioters. In the main their voices have not been heard... in this regard, it would be most helpful therefore if the media obtained more interviews with the culprits, just as Sky News, for instance did on Friday 12 August, with their interviews with four track-suited, hooded youths...

While his key aim is to advance societal factors that influenced the events that began on 6 August; by referring to the protagonists as 'culprits' and the events as 'riots', his central focus of analysis are social actors that have already been criminalised and delegitimised, rather than individuals who were exercising their legal right to protest. He also repeats and therefore perpetuates (rather than critique) the stereotypical representation of the main protagonists by Sky News, who interviewed young males wearing hooded tracksuits. The 'hoodie' is already associated with criminality due to being the focus of Anti-Social Behaviour Orders, framed as a moral panic (Wayne et al, 2008). Mitchell does however, attempt to advance causes for the disturbances that are de-racialised that include: the impact of the recession; the police service-including deaths in police custody and fewer employment opportunities.

\section{Stephen Lawrence Verdict: justice at last?}

January 2012 brought the conviction of Gary Dobson and David Norris for the murder of Stephen Lawrence marking the conclusion of a 20-year campaign for justice. The Independent (Cathcart, 2012) ran a story headlined: 'The life and legacy of Stephen Lawrence' which featured interviews with the parents of the murdered teenager. Speaking of her son's life, Doreen Lawrence said:

Now that we have some sort of justice, I want people to think of Stephen other than as a Black teenager murdered in a racist attack in south-east London...I want him to be remembered as a bright young man...He was a wonderful son and a shining example of what any parent would want in a child. Hopefully now he can rest in peace. 
The political significance of the events and actions that followed the death of Stephen Lawrence, driven largely by the persistence of his parents is now embedded in the history of race relations in Britain as Hall et al (2013: introduction) assert:

Arguably the most significant single event that was ultimately to propel the issue of violent racism to the top of the political and social agenda was the murder of Black teenager Stephen Lawrence in April 1993.

Grace, a 35 year old woman, uses a fictional character called Ebony to write commentaries from a Black, female perspective. During an interview she stressed the importance of her positionality: 'It's important that people understand that it's written by a Black woman because I can get quite political and quite rebellious and I want to be quite authentic ...' The articulation of a Black woman's standpoint is a strategy used to resist raced, classed and gendered oppression and represents spaces that Black women create to construct their own self-definitions and oppose dominant constructions of Black female identity (Collins, 1990). The authenticity of Black identity and the Black experience is highly contested. Efforts to challenge negative representations of African Caribbean people in Britain through cultural projects in the seventies seeking to counter objectification by presenting 'authentic' images of Blackness have been criticised for reproducing essentialist notions of Black identity (Hall, 1996; Marotta, 2001). However, authenticity as a dimension of blogging practice represents the dissemination of experiential knowledge based on unique perspectives that serve as counter-narratives to dominant discourses It functions as a tool against raced and gendered oppression that does not necessarily reflect the belief of a homogenous Black identity but represents a political position from which people of colour explore, negotiate and define their own subjective reality. Speaking through her alto ego Ebony, Grace writes:

News outlets all over the UK hail Stephen Lawrence's murder as the catalyst that implemented an overhaul of how the British Law system works. How racist incidents are treated. How serious the UK takes racial crimes.

Yet whilst these British stalwarts get to back slapping and hoorah-ing all I can hear running through my mind are the words of the most absolute representation of strength, determination and fearlessness that is Ms Doreen Lawrence:

The fact is that racism and racist attacks are still happening in this country and the police should not use my son's name to say that we can move on.

Ms Lawrence is right. It is not a time to celebrate. Not at all. Because whenever 'we' talk about racism we're told off for stirring up trouble, carrying chips on our shoulders, dragging up the past, imagining things, being oh so boring.

I guess, yes of course, it must be so tiresome to hear the natives complaining about their lot. I mean gosh darn it we the natives should be grateful to have been rescued from walking around the bloody jungle naked except for strategically placed bones and cooking each other for tea and what not! Indeed, master indeed.

During interview, Grace explains that adopting Ebony as an alter ego is a way of informing and educating her audiences through humour: 'I kind of have this thing of educating through humour, so it's kind of getting points across with a bit of tongue-in-cheek'. Her unique approach is a strategy for challenging hegemony-by demonstrating 'that there are alternative ways of seeing the world and other stories to be told' (Lievrouw, 2011: 372). She uses the 
powerful words of Doreen Lawrence who maintains that there is no reason to celebrate the Stephen Lawrence verdict due to continued racist attacks; to remind her audiences that racist discourse still prevails and this represents another form of racial oppression. She argues that in the mainstream media, the perspectives of African Caribbean people are delegitimised as any reference to their experiences of racism in contemporary society are framed as resulting from their failure to assimilate into the dominant culture. Racial neoliberalism is defined as the process of 'de-racialisation in order to promote post-racialism' (De Genova, 2010 cited in Kapoor, 2013:1028). This manifests in discourse that asserts that race is no longer the primary determinant of social and economic outcomes, and to name and acknowledge race is deemed problematic- a point that Grace articulates well in the above post.

Chioma, a 48 year old woman writing on the topics of race, gender and politics also emphasises the importance of her positionality from a Black female standpoint: 'I'm a UK African woman...I was talking about being voiceless in a society that doesn't hear me...having the blog was part of me using my voice'. In her post on the Stephen Lawrence verdict she writes:

I remember staring into the wistful and innocent gaze of Stephen Lawrence... a smile that held promises of so many things to come in his life. And then he was stabbed relentlessly to death by virulent and venomous racists, who chased him down like a runaway slave and who took away his dreams and evaporated his own destiny...

This made me even more aware that living within this multicultural society was just a dream. It was not utopia. I had fear. I had an unhealthy, almost pathological fear for my boys that they would one day end up as a statistic and a blot on this vanilla landscape.

I attended the Macpherson Inquiry at Hannibal House in Elephant and Castle in June 1998. I saw the smirk of those white men who casually sauntered away with blood on their hands and murder on their conscience.

Today is a bittersweet day for me I will never forget. It had a huge impact on me, a mother [of] two young black men... I cry tears for Stephen Lawrence and the extent of SOME justice for him; my tears will still flow every now and then until there is a fair completion... until all of the murderers involved are convicted and sentenced.

I pray that they will also be held responsible for Stephen's murder as well. That is why I have written that SOME justice has been meted out today. It's not complete but I remain forever optimistic.

While Grace focuses on how the mainstream media perpetuates racist discourse, Chioma's post is centred on the perspective of Black mothers and their fears for their own sons, heightened by the failure of the Metropolitan Police to bring all the killers involved in the murder to justice. She also draws on imagery linked to the historical experience of slavery by African Caribbean people, through an analogy depicting the manner in which runaway slaves were hunted and brought to death, in a similar fashion to the murder of Stephen Lawrence, also pursued and killed by white males. This statement echoes a key tenet of cultural democracy-that marginalised groups should be able 'to speak in a culturally authentic, socially meaningful and politically powerful voice’ (Aldridge, 2000: 103). 


\section{Conclusion}

The narratives presented in this study serve an important purpose in privileging the voices of African Caribbean bloggers in this study and in acknowledging their role in the construction of new knowledge arising from these findings. Blogs function as an important medium that enables African Caribbean people to create and interpret events as counter-narratives in opposition to dominant discourses. This is of major significance since power and privilege are unevenly distributed across all cultural and social arenas and as such can only be challenged through 'democratic practice' (Aldridge, 2000:102). The findings demonstrate that the bloggers featured in this study appropriate blogs as a medium for self-representation, leading to the cultivation of symbolic power through their own constructions of Black identity and social life.

In their role as historical archives, extracts of the blog posts analysed in this study demonstrate their usefulness in challenging homogenised representations of Black identity and in reflecting the varied perspectives of the bloggers in relation to their experiences as racialised minorities in Britain. Valdes et al (2002:244) argue that this is an effective strategy for resisting stereotypes perpetuated through the dominant culture 'by representing people of colour as complex and heterogeneous'. Another important outcome is that through powerful counter-narratives, blogs perform an important role in creating alternative perspectives that reframe historical events in ways that have meaning and significance to Black communities.

As historical archives blogs have played an important role in capturing key historical moments and this study highlights the role of African Caribbean bloggers as co-creators of British social history; helping to generate new levels of understanding on the lived experiences of racialised minorities and challenging the whiteness of Britishness.

\section{References}

Ainley, B. (1998). Black journalists, white media. London: Trentham.

Aldridge, D. (2000). On race and culture: beyond Afrocentrism, Eurocentrism to cultural democracy. Sociological Focus. 33:1; pp.95-107

Allan, S. (2006). Online News: Journalism And The Internet: Berkshire; Open University Press. 
Bailey, O., Cammaerts, B., \& Carpentier, N. (2008). Understanding alternative media. Maidenhead: Open University Press.

BBC News (2014, 8 January). Mark Duggan death: timelime of events. Retrieved from http://www.bbc.co.uk/news/uk-england-london-14842416

Bressey, C. (2006). Invisible presence: the whitening of the Black Community in the Historical Imagination of British Archives. Archivaria, 61(1), pp.47-61.

Brock, A. (2009). Who do you think you are? Race, representation, and cultural rhetorics in online spaces. Poroi, 6(1), p.3.

Brock, A., Kvasny, L., \& Hales, K .(2010). Cultural appropriations of technical capital. Information, Communication and Society 13(7), pp.1040-1059.

Campbell, A. (2008). Without 'you' I'm nothing: making white Britishness online. Social Semiotics, 18 (4). pp. 409-424.

Cammaerts, B. (2008). Critiques on the participatory potential of web 2.0. Communication, Culture \& Critique, 1(4). pp.358-377.

Carter, B., Green, M., \& Halpern, R. (1996). Immigration policy and the racialization of migrant labour: The construction of national identities in the USA and Britain. Ethnic and Racial Studies, 19(1), pp. 135-157.

Cathcart, B. (2012, 8 January). The life and legacy of Stephen Lawrence. Independent. Retrieved from http://www.independent.co.uk/news/uk/crime/the-life-and-legacy-ofstephen-lawrence-6286671.html

Chen, X. (2010). Blog archiving issues: a look at blogs on major events and popular blogs. Internet Reference Services Quarterly, 15(1), pp.21-33.

Cohen, D. J. (2005). The future of preserving the past. CRM-WASHINGTON, 2(2), pp.6.

Collins, P. H. (1990). Black feminist thought: knowledge, consciousness and the politics of empowerment. New York: Unwin Hyman.

Cottle, S. (2000). Ethnic minorities and the media. Maidenhead: Open University Press.

Delgado, R., \& Stefancic, J. (2001). Critical race theory: an introduction. USA: Temple University Press.

Downing, J. (2001). Radical media: rebellious communications and social movements. Canada: Sage.

Fiske, J. (2000). White watch. In S. Cottle (Ed.), Ethnic minorities and the media. (pp. 5066). Maidenhead: Open University Press.

Gabriel, J. (1998). Whitewash: racialised politics and the media. London: Routledge.

Gaudio, R. P., \& Bialostok, S. (2005). The trouble with culture: Everyday racism in white middle-class discourse. Critical Discourse Studies, 2(1), pp.51-69.

Gee, J. P. (2005) An introduction to discourse analysis: theory and method. Oxford: Routledge.

Gilbert, J. (2013). Common Ground: Democracy and collectivity in an age of individualism. London: Pluto Press.

Gillborn, D. (2008). Racism and education: Coincidence or conspiracy? Oxon: Routledge.

Gurak, L. J., \& Antonijevic, S. (2008). The psychology of blogging. American Behavioral Scientist, 52(1), pp.60-68.

Hall, S. (1996 ). New ethnicities. In: Morley, D. \& Chen, K.H. (Eds.), Critical dialogues in cultural studies (pp.441-449). London: Routledge.

Hall, N., Grieve, J., \& Savage, S. (Eds.). (2013). Policing the Legacy of Lawrence. Willan.

Harding, J. (2013). Qualitative data analysis from start to finish. London: Sage.

Hill, J. H. (2011). The everyday language of white racism. W.Sussex:Wiley-Blackwell. 
Institute for Public Policy Research (2010). Recession leaves almost half young black people unemployed, finds IPPR. Retrieved from http://www.ippr.org/news-and-media/pressreleases/recession-leaves-almost-half-young-black-people-unemployed-finds-ippr

Jensen, T. (2013). Riots, Restraint and the New Cultural Politics of Wanting.Sociological Research Online, 18(4), p.7. Retrieved from http://www.socresonline.org.uk/18/4/7.html

Journalism Training Forum. (2002). Journalists at Work. UK: Publishing NTO/Skillset.

Kaplan, A. M., \& Haenlein, M. (2010). Users of the world, unite! The challenges and opportunities of Social Media. Business horizons, 53(1), pp.59-68.

Kapoor, N. (2013). The advancement of racial neoliberalism in Britain. Ethnic and Racial Studies, 36(6), pp.1028-1046.

Kendall, F. E. (2006). Understanding white privilege: Creating pathways to authentic relationships across race. New York: Routledge.

Kretzschmar, S. (2007). Diverse journalists in a diverse Europe? Impulses for a discussion on media and integration. European Studies: A Journal of European Culture, History and Politics, 24(1): 203-226.

Law, I. (2002). Race in the News.: London: Palgrave Macmillan.

LeCompte, M. D. (2000). Analyzing qualitative data. Theory into Practice, 39(3), pp. 146154.

Leonardo, Z.(2004). The colour of supremacy: beyond the discourse of 'white privilege'. Educational Philosophy and theory incorporating ACCESS. 36(2):137-152).

Leow, R. (2010). Reflections on Feminism, Blogging, and the Historical Profession. Journal of Women's History, 22(4), pp.235-243.

Lievrouw, L. (2011). Alternative and activist new media. Cambridge: Polity Press.

Marotta, V. (2001). New online ethnicities and the politics of representation. Journal of Intercultural Studies, 32(5) pp. 539-553.

McIntosh, P. (1998). White privilege: Unpacking the invisible knapsack. Excerpt from White privilege and male privilege: A personal account of coming to see correspondence through work in women's studies. Wellesley, MA: Wellesley College Center for Research on Women. Working paper (189).

Mclaughlin, E., \& Neal, S. (2004). Misrepresenting the multicultural nation: The policymaking process, news media management and the parekh report. Policy Studies, 25(3), pp.155-174

Milner, H.R, (2007). Race, culture and researcher positionality: working through dangers seen, unseen and unforeseen. Educational researcher, 36(7), pp.388-400.

Moyo, L. (2011). Blogging down a dictatorship: Human rights, citizen journalists and the right to communicate in Zimbabwe. Journalism Theory Practice and Criticism, 12(6). pp.745-760.

O'Sullivan, C. (2005). Diaries, on-line diaries, and the future loss to archives; or, blogs and the blogging bloggers who blog them. American Archivist, 68(1), pp.53-73.

Owen, D. S. (2007). Towards a critical theory of whiteness. Philosophy \& social criticism, 33(2), pp.203-222.

Parekh, B. (2000). The Parekh Report: The future of multi-ethnic Britain. London: The Runnymede Trust.

Phillips, C. (2011). Institutional racism and ethnic inequalities: an expanded multilevel framework. Journal of social policy, 40(1), pp.173-192.

Phoenix, A., \& Phoenix, A. (2012). racialisation, relationality and riots: intersections and interpellations. feminist review, 100(1), pp.52-71. 
Pole, A. (2005). Black bloggers and the blogosphere. Paper presented at the The Second International Conference on Technology, Hyberbad, India. Retrieved from http://www.mdcbowen.org/cobb/archives/pole_black_bloggers.pdf

Pole, A. (2009). Blogging minorities: Black and Hispanic political bloggers and participation in the United States. Paper presented at the ISA Annual Convention, New York.

Radsch, C. (2008). Core to commonplace: The evolution of Egypt's blogosphere. Arab Media \& Society, 6 .

Sommers, S. R., Apfelbaum, E. P., Dukes, K. N., Toosi, N., \& Wang, E. J. (2006). Race and media coverage of Hurricane Katrina: Analysis, implications, and future research questions. Analyses of Social Issues and Public Policy,6(1), pp.39-55.

Thomas, D. R. (2006). A general inductive approach for analyzing qualitative evaluation data. American Journal of Evaluation, 27(2), pp. 237-246.

Troutt, D. D. (2006). After the storm: Black intellectuals explore the meaning of Hurricane Katrina. New Press.

Valdes, F., Culp, J \& Harris, A (2002) Crossroads, Directions and a New Critical Race Theory. Philadelphia: Temple Press

Van Dijk, T. A. (2000). New (s) racism: A discourse analytical approach. In Cottle, S. (Ed.), Ethnic minorities and the media (pp.33-49). Maidenhead: Open University Press.

Van Dijk, T. A. (2006). Racism and the European press. Presentation for the European Commission against Racism and Intolerance (ECRI), Strasbourg, 16. Retrieved from http://www.discourses.org/Racism\%20and\%20the\%20European\%20press.html

Wayne, M., Henderson, L., Murray, C \& Petley, J. (2008). Television news and the symbolic criminalisation of young people, Journalism Studies, 9(1), pp.75-90. 